\title{
Changes in Indigenous Coping Strategies over the last two Decades in Shanta-Abaq Division, Lagdera District, Garissa County, Kenya
}

\author{
Nur Ibrahim Mohamed ${ }^{1}$, Eric Kiprono Bor $(\mathrm{PhD})^{2}$, Professor Abdullahi A. Aboud (PhD) ${ }^{3}$ \\ ${ }^{1}$ Graduate Student, Egerton University, Department of Peace, Security and Social Studies \\ ${ }^{2}$ Lecturer/Consultant, Egerton University, Department of Peace, Security and Social Studies \\ ${ }^{3}$ Senior Lecturer/Consultant, Egerton University, Department of Natural Resources
}

\begin{abstract}
This study was undertaken in Lagdera District of Garissa County, a semi-arid area where nomadic pastoralism forms the bedrock of people's livelihoods. The study aimed to analyze pastoralist's household livelihood vulnerability to drought hazards over the last two decades. The study was motivated by several concerns. First, there is need to understand the vulnerability of pastoralist livelihoods to drought hazards in the arid and semi-arid areas of Kenya. This will help us understand the dynamics and root causes of the existing high level of poverty in the region. Second, by understanding the factors that constrain or have weakened community coping strategies to drought hazards, it is possible to design interventions in such a way that they address the constraints to the highly evolved strategies and improve community resilience to drought hazards. Participatory tools such as Household and Key Informant Interviews, Historical Timelines and Focus Group Discussions were used to collect primary data from five locations of Shanta-Abaq division of Lagdera district, Garissa County of North East Kenya. Two hundred respondents, 40 from each of the five locations, were randomly picked and interviewed. In the analysis of data, the study used the Statistical Package for The Social Science (SPSS), a statistical tool for data analysis. The study findings indicate that the policy of sedentarization promoted by the government from nineteen sixties, an increase in human population following the entry of refugees from Somalia into the district, and conflict with neighbouring communities that curtailed herd mobility, have combined to undermine the ability of pastoralist population in the study area to respond to environmental hazards such as drought thus, increasing their vulnerability. Over the last two decades, $72 \%$ of the households in the study area have dropped into poverty after losing $50 \%$ of their livestock to successive droughts. To cope with the increasing vulnerability; households have adjusted their coping mechanisms. First, they are moving away from relying on a single livestock species, cattle, to diversifying their species composition and second, engage in other sources of income for survival. In addition, communities in the study area are no longer confident that they can cope with the recurring disaster that is common in their environment. Majority of the households (75\%) in the study area feel that their ability to cope with drought hazards is weak and as a result they remain vulnerable to the recurring drought hazards.
\end{abstract}

Key words: changes, indigenous, coping strategies, semi-arid areas

\section{Introduction}

Pastoralism is an ancient production system. Its major influence was probably felt as early as $3000 \mathrm{BC}$ in East and West Africa [7]. Over their long history, pastoralists have risen and fallen as a result of shocks to their livelihood. When they fall as a result of a hazard, they have always managed to recover and rise again. These hazards include drought, disease epidemics and conflict.

In the Horn of Africa, pastoralists inhabit arid and semi-arid lands, which are prone to frequent drought hazards. However, they have over centuries learnt to adapt to this climatic shock and built their livelihoods in this vulnerability context. They have developed a range of relevant, appropriate and dynamic coping strategies to protect their livelihoods against the impacts of these hazards. Western and Nightingale [31] contend that pastoralists use a variety of mechanisms to ensure the survival and productivity of their herds and reduce their vulnerability to climatic shocks.

In the above context, the main strategies used by pastoralists to cushion themselves against drought hazards include mobility, which involves movement of people and their stock over a large geographic area to exploit scarce grazing and water resources, large and diversified herds, and social relations that they rely on in times of crisis[20]. Built on these coping strategies, Pastoralism is so far the most suitable livelihood system in the dry lands of the Horn of Africa. Presently, it is the main economic activity upon which the lives of the people in the region depend on and makes a significant contribution to the Gross Domestic Product of many countries of the region [3]. This situation is also common to Lagdera District of Garissa County in Kenya.

An overview of the situation in the last two decades indicates that the vulnerability of pastoralist livelihoods to drought hazard has increased. Their ability to recover from shocks to their livelihoods has also diminished. Despite continuous emergency support from the Government and Humanitarian Organizations, household herd size has diminished and the trend appears worrying [26].

Vulnerability is about the future not the present [9], [10]. Vulnerability information gives a picture of the future condition since it is about linking the present to the future. It can give an indication of what may happen to a given population in situations of particular hazards. In arid and semi-arid areas of Kenya where recurring crisis is becoming 


\section{International Journal of Science and Research (IJSR) ISSN (Online): 2319-7064 \\ Index Copernicus Value (2013): 6.14 | Impact Factor (2014): 5.611}

a common phenomenon, vulnerability information will give an indication of what might happen to affected households in the next cycle of shock.

\subsection{Problem Statement}

Pastoralist communities have over centuries learnt to adapt to drought and other hazards that is characteristic of their environment. They have developed highly evolved coping strategies based on their indigenous knowledge and experience of adapting to climatic variations to cushion themselves against the impacts of these hazards. However, over the last two decades the ability of pastoralist livelihoods to cope with drought hazards in North-East Kenya has reduced. This is evidenced by the high numbers of livestock lost in every drought that hit the region and the growing numbers of destitute as a result of these hazards. However, there is hardly a study that has been done on the changes of indigenous coping strategies over the last two decades in Shanta-Abaq division of Lagdera district, Garissa County, Kenya.

\subsection{Justification of the Study}

This study was motivated by several concerns. First, there was the need to understand vulnerability of pastoralist livelihoods to drought hazards in the arid and semi-arid areas of Kenya. This will help us understand the dynamics and root causes of the existing high level of poverty in the region since vulnerability if unaddressed will lead to poverty. It is now widely acknowledged that yesterdayes vulnerability is todayes poverty.

Second, pastoralism is the main economic activity and source of livelihood for the majority of people in arid and semi-arid areas of Kenya. In order to save these livestockbased livelihoods during drought-induced disasters, Governments, Humanitarian organizations in the Horn of Africa and the International donor community need to have a deeper understanding of vulnerabilities of the pastoralists ${ }^{\text {ee }}$ people to future shocks upon which preparedness measures can be based. This study about factors that explain vulnerability of pastoralist communities to drought should be a contribution to this understanding.

\section{Literature Review}

A large body of literature on indigenous coping strategies that pastoralists use to protect their livestock-based livelihoods against hazards exist; [23], [21], [11], [5], [13], [25]. Key strategies that have been documented include large and diversified herd size, drawing on social relations during periods of crisis, and spatial mobility among others. A characteristic of pastoral people is to protect their herds against natural risks through various strategic methods, such as diversification of their herds, sharing and loaning stock, migration, auxiliary activities, and food storage (on the hoof) [2]. However, these coping strategies are dynamic responses that are prone to change as socio-economic circumstances of a given community change, though few studies have examined this dynamism [8].
The grazing territory of the herders in Shanta-Abaq includes their own clan territory and those of other clans and it also cuts across the Kenya/Somalia border. They criss-cross the boundary between Kenya and Somalia in search of pastures and water for their livestock. For example, herders would be in Somalia during the Jilaal (dry period) from JanuaryMarch and move their livestock back to Kenya for the rest of the year. Equally they can move to other neighboring regions like Isiolo, Tana River or Garissa district during drought periods when pastures in their territory are depleted and move back when it rains and conditions are favorable. This spatial mobility, which involves movement of people and stocks over a large geographic area to exploit scarce resources characteristic of the arid environment is a key feature of the pastoralist livelihood system. These movements can be within a specific clan/group territory or longer transhumance movements across different territories sometimes traversing international borders. Stock migration is an obvious strategy for survival, according to [2]. Such migrations can take the form of simple, seasonal transhumance, or the long distance nomadic movements. Pastoral nomadism is thus an adaptive measure in coping with disasters.

Several researchers have examined factors that constrain spatial mobility in different pastoralist communities in the Horn of Africa. While studying livelihoods of Beja pastoralists in the Red Sea State of Sudan, [5] noted that shortage of labor had limited the capacity of rural Beja to resort to longer transhumance movements at certain times of the year or at times of crisis when the ability to reach faraway pasture reserves is crucial for the survival of the animals. While studying pastoralists' livelihoods in Southern Ethiopia, [13] had a different finding. He contends that households differ in their ability and willingness to migrate to distant areas. The implication is that even with labor availability some households may not be willing to migrate to distant areas.

In Northern Turkana food aid is one of the main factors that had constrained pastoralist mobility [18]. He notes that where members of the family receive food aid, there was a strong incentive for the herd-owners to try to remain within the locality of relief centers. Though food aid is one of the major responses taken by Kenyan government and aid agencies during droughts in the study area, the target has always been the poor households in the community. The wealthy and better off households are not normally covered by food aid.

According to [14] and [18], conflict between rival communities in Turkana and Kitui districts, had restricted pastoralist household access to some key grazing resources and forced them to adjust their movements to avoid insecure areas even when these areas have adequate grazing resources. Conflicts occur in different forms: inter-clan conflict over resources, raiding livestock, and civil war. In Turkana district, cattle raiding between the Karamajong and Turkana are the major sources of insecurity that have constrained pastoralist mobility. However, cattle raiding is not a common practice among the Somali pastoralists but conflicts over access to resources are common. 


\section{International Journal of Science and Research (IJSR) \\ ISSN (Online): 2319-7064 \\ Index Copernicus Value (2013): 6.14 | Impact Factor (2014): 5.611}

In a synthesis paper on demographic trends, settlement patterns and service provision in pastoralism, [11] argue that inappropriate polices towards pastoralist areas in Eastern Africa including Kenya that advocated for sedenterization of pastoralists have disrupted the traditional mobility of pastoralist communities in the arid and semi-arid areas. The policy of sedenterization has led to increased number of settlements over the last two decades in Northern Kenya.

Though several studies have examined the factors that constrain pastoralist mobility, the link between mobility and vulnerability is not clear. This study therefore, examined how mobility across this large geographic area has changed, what were the factors that constrained or enhanced this mobility and how did this influence household vulnerability. In addition, the study also examined changes in frequency of these movements within the clan territory both during normal years and during drought periods.

Social capital is a major livelihood asset that has an influence on household vulnerability though often it is overlooked. Pastoralists have always drawn on social resources in their communities to cope with crises. Social capital implies that there are aspects of social structure or organization that act as resources for individuals or households allowing them to realize their personal aims and interests. It is governed by cultural norms and values and it is embedded in the clan, kinship networks or ties, membership of formal/informal groups, relationship of trust, reciprocal relationships and sharing of information and knowledge [26].

Within a clan, social resources are available at different levels: at the clan and at kinship levels. Access to these resources varies with the level at which it is available. Social resources available at the clan level are accessible to all members of that clan. While social resources available at kinship level, or limited group level are restricted to individual households in that kinship ties or group. For instance, a clan identifies itself with a certain territory and/or resources and being a member of that clan implies access rights to those resources [6]. [22] contend that social capital provides safety nets within a kinship network, and helps members in the negotiation of access to vital resources such as grazing, resolution of conflicts, management of common resources through traditional norms and values, and facilitates distant movement of herds through labor support, and minimizes risks.

Loaning animals and sharing herds is one very important part, not only for survival strategies, but also the building up of social contacts and bonds within the group. For example the Pokot (as well as herdsmen of many other groups) have an intricate system of "stock Friends". Such relations are ideally built up with friends spread as widely as possible so as to have some stock left elsewhere in time of a catastrophe. Thus the concept of "Stock Friends" does not only involve loaning and sharing herds, but also borrowing breeding or milking animals to improve one ee herd, or to subsist on his friends stock in time of difficulties [1].

Among the Somali, like many other pastoralist communities, livestock though owned individually are viewed principally as a community asset whose protection and reproduction is a collective responsibility. [29] note that among the Boran of Southern Ethiopia, a man would say "our cattle" instead of "my cattle" signifying the collective ownership of the resource. Since livestock is viewed as a community asset their massive loss to drought or raids is seen as a disaster to the entire clan. To reduce such a disaster, the Somali society has well developed social networks that help individual households to minimize livestock losses during crisis, promote reproduction of the herds and avoid hunger. However, different households have differential access to these social resources in a given community. This access or lack of it influences individual household 's vulnerability to disaster. [12] note that poor households with limited social resources will be hard hit by drought hazards-triggered crises and will be less likely to recover from disasters. However, no study has documented social resources that are available to households in the study area and how this has changed over time and how it affects household vulnerability.

Herd diversification is a strategy of dealing with a risky environment and situations. This is based on the principle of feed preference for different types of livestock, and that each type will occupy or utilize different ecological niches of the environment and so have different chances of survival [2]. Choosing which animals to keep depends on a combination of ecological factors, socio-cultural values and market options. Livestock are not only a saleable asset, but also provide income and food in the form of meat, milk, labor, and hides and skins, as well as conveying social status on their owners and playing a major role in establishing and developing social assets. By combining diverse and complementary animal species (small and large nonruminants, browsers and grazers, etc.) pastoralists are able to convert rangeland vegetation into mobile stocks of protein, reduce risks and to diversify their income - satisfying both their material and social needs. This is a key coping mechanism pastoralist households employ against climatic variability that is characteristic of their environment. In response to external shocks, pastoralist households have tended to accumulate and diversify herd composition and species as coping strategy [11]. Diversifying herd composition and species helps households to exploit fully the diverse flora and cope with climatic variability. A study found out that households in Mandera West were reluctant to keep cattle as they do not do as well as goats and camels particularly in the wake of the recurring droughts in the region [32]. However, there is hardly any study that examined herd diversification and its impact on household vulnerability in the study area. This study attempted to address this gap by looking at the level of herd diversification in the study area and how this changed over the last two decades.

\section{Methodology}

The study area, Shanta-Abaq division, is located in Lagdera district of North Eastern Province, Kenya. The area is inhabited by Aulihan sub-clan of the Ogaden clan of the Somali ethnic group. Somali society is sub-divided into clan families, which also sub-divides into very close kinship group. Members of a sub-clan normally occupy a given

\section{Volume 4 Issue 11, November 2015}




\section{International Journal of Science and Research (IJSR) \\ ISSN (Online): 2319-7064 \\ Index Copernicus Value (2013): 6.14 | Impact Factor (2014): 5.611}

geographic area and identify with such a territory and control all the resources within their territory. The study utilized survey research design to collect data from a sample population using both interview and structured questionnaire. The survey design was selected because it can facilitate the collection of a wide range of information from a large number of respondents in relatively short period of time.

The study population was the pastoralist households in Shanta-Abaq division of Lagdera district of Kenya who own livestock and whose livelihoods depend on livestock whether wholly or in part. The study drew samples from the five locations that form Shanta-Abaq division namely, Baraki, Gurufa, Goreale, Afwein and Chevron. Stratified cluster sampling design was used to draw samples from the study area. A total of 200 respondents were obtained through this probability sampling techniques for interview by the researcher from the selected locations. This sample represents $9 \%$ of the total human population in the study area that forms the study frame.

Sources of data included household heads, Key Informants Interviews, Focus Group Discussions, Non-participant Observation and documented sources. Quantitative data were collected using questionnaires, which were examined and edited to assess for completeness and consistency. Descriptive statistics such as frequency tables, pie-charts and percentages were used to contrast households ${ }^{\text {ee }}$ livelihood assets, changes in coping strategies and the factors that have constrained access of pastoralists to resources. Focus Group Discussions were used for participatory vulnerability analysis, where the local communities were involved in breaking down their vulnerabilities into component parts, which can be understood and addressed. The analyses were used to enrich quantitative data from sample households.

\section{Data Analysis and Interpretation}

\subsection{Response Rate}

The study succeeded in interviewing all the 200 households using semi-structured questionnaires. This represented a $100 \%$ response rate, which is considered satisfactory to make conclusions for the study. This high response rate can be attributed to the data collection procedures, where the researcher personally administered semi-structured questionnaires and filled in the response from the respondents. According to [19]; a 50\% response rate is adequate, $60 \%$ good and above $70 \%$ is rated very good. Based on this, the response rate of $100 \%$ in this study is regarded as very good.

\subsection{The Characteristics of the Respondents}

\subsubsection{Age and Gender of Respondents}

As can be seen from Figure1 below, majority of the respondents in the study were males at $59 \%$ while the remaining $41 \%$ were females. Somali society is a patriarchal society where men are the heads of households. Household decision making has been a preserve for men while women, though they contribute significantly to household labor, have limited decision making authority. However, the survey shows more women assuming the role of heads of households and they were quite knowledgeable on their households ${ }^{\text {ee }}$ conditions. Probably women in the study area are playing this role in the absence of their husbands and might not really signify a shift in gender relations in the community.

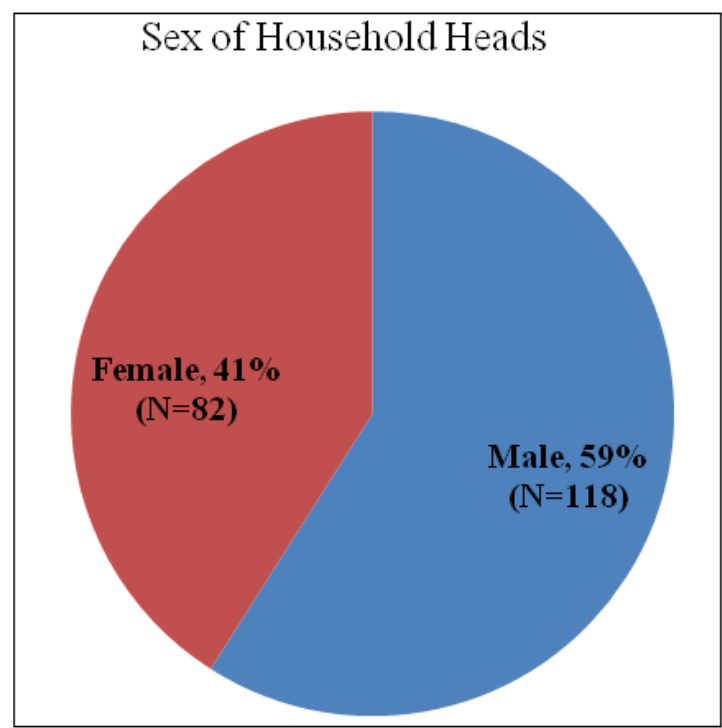

Figure 1: Sex of Respondents

The survey shows that the mean age of the respondents was 44.09 years with the youngest at 16 and the oldest at 93 years as tabulated in Table 1 below. The median age of the respondents was 40 years.

Table 1: Age of Household Heads

\begin{tabular}{|l|l|}
\hline Number valid & 200 \\
\hline Mean & 44.09 \\
\hline Median & 40.0 \\
\hline Standard deviation & 15.631 \\
\hline Minimum & 16 \\
\hline Maximum & $\mathbf{9 3}$ \\
\hline
\end{tabular}

From the survey, it is evident that $98 \%$ of respondents were either the head of households or the spouse and were knowledgeable on all their households ${ }^{\text {ee }}$ status.

\subsubsection{Marital Status of Respondents}

As can be seen from Figure 2 below; majority of the respondents $(92 \%)$ were married with only $4 \%$ divorced, $2 \%$ widowed and $2 \%$ single. The number of women divorced is higher than those widowed. In traditional Somali society single parenthood is uncommon. Where a woman is divorced or widowed re-marriage are allowed and is quite common. However, in view of the current social change this is possible. This probably explains why only $6 \%$ of the respondents are divorced, widowed or single. 


\section{International Journal of Science and Research (IJSR) \\ ISSN (Online): 2319-7064}

Index Copernicus Value (2013): 6.14 | Impact Factor (2014): 5.611

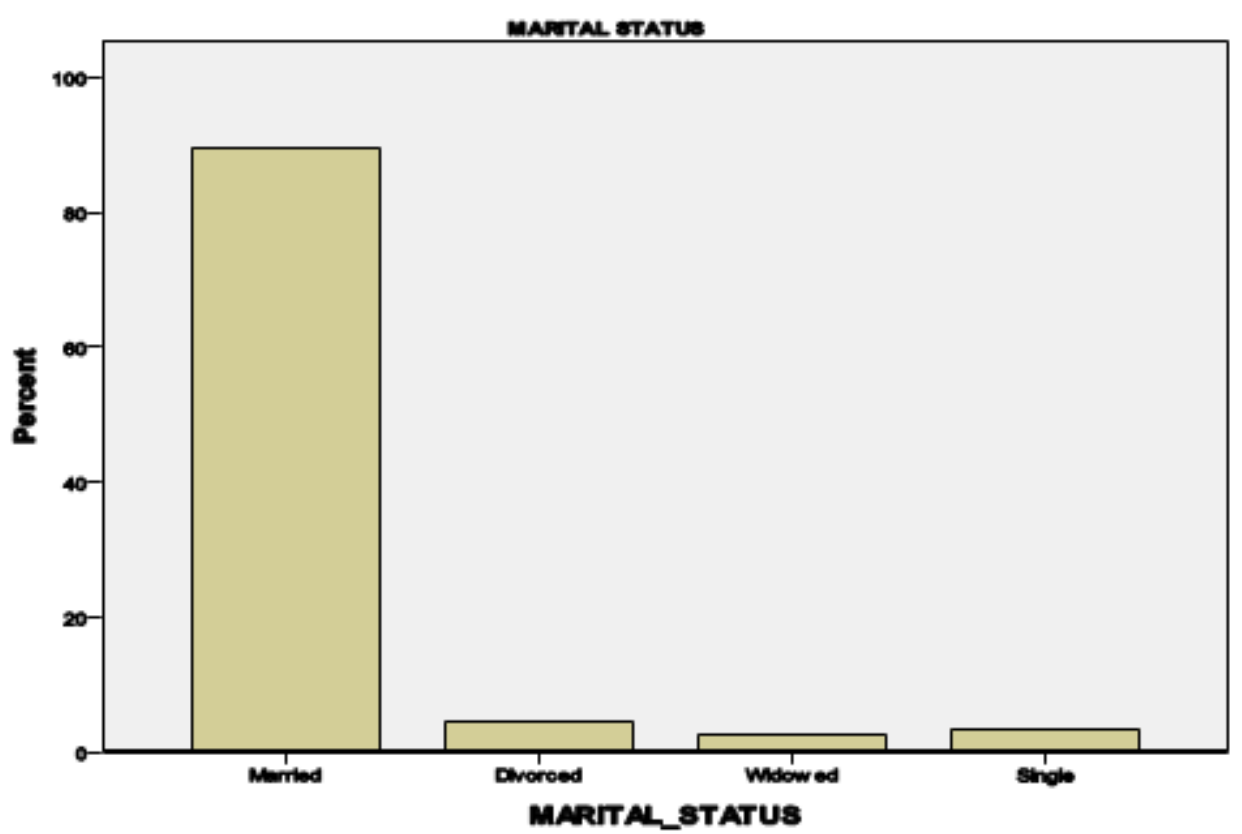

Figure 2: Marital Status of Household Heads

\subsubsection{Literacy and Educational Level of Respondents}

The survey shows that the level of illiteracy among the respondents was quite high. Out of a total sample of 200 respondents, 152 of them representing $76 \%$ of the respondents can $\mathrm{t} t$ read or write any language as illustrated in Table 2 below. Only $20.5 \%$ are able to read or write in English or Kiswahili while 2\% can read Arabic and 1\% are able to read Somali language. These figures are in line with the Human Development Indices that indicate that north east Kenya has the lowest literacy rates for the population 15 years and above in the country at $28 \%$ against $79 \%$ nationally.

The study findings further show that out of those who have never attended any school, $54 \%$ are female while $46 \%$ are male as demonstrated by Table 2 below. Out of 41 respondents who indicated that they can read and write English or Kiswahili, 40 were male. While out of 81 female respondents only one could read and write. The rest have not attended school as indicated in Table 2 below. This demonstrates that illiteracy is higher among women than in men in the pastoralist community in the study area.

Table 2: Literacy Level of Respondents

\begin{tabular}{|l|c|c|}
\hline Literacy level of respondents & Frequency & Percentage \\
\hline Can read and write Somali & 2 & $1 \%$ \\
Can read and write Arabic & 4 & $2 \%$ \\
Can read and write Arabic and Somali & 1 & $0.5 \%$ \\
Can read and write English or Kiswahili & 41 & $20.5 \%$ \\
Cannot read or write any language & 152 & $76 \%$ \\
Total & $\mathbf{2 0 0}$ & $\mathbf{1 0 0 \%}$ \\
\hline
\end{tabular}

(Source: Household Interviews)

Access to education particularly for the girl child has been a problematic issue for the pastoralist communities in N.E. Kenya. The region has the lowest gender parity index of 0.51 implying there are only 51 girls for every 100 boys enrolled [24]. According to [24], some of the deterrent factors in girls ${ }^{e e}$ access to primary education in N.E. Kenya include long distance to schools, which disadvantage girls due to other home care activities, cultural bias in favor of boys, early marriages and associated parental responsibilities leading to drop-outs, heavy workload for female pupils at household level, high poverty incidence and unfavorable schooling environment that does not favor girls especially at adolescent stage. This explains the high level of illiteracy among the female respondents in the study area.

\subsubsection{Educational Level of Respondents}

The survey shows that over a third of the respondents $(76 \%)$ reported that they have never attended school and as a result remained illiterate as can be seen from Table 3 below. Those who had basic primary education were $18 \%$ while $2 \%$ had reached secondary level of education and $4 \%$ went through non-formal education in literacy and numeracy skills. The findings show that even for those who complete primary education transition to secondary education is very low. This explains why none of the respondents have university education.

Table 3: Education Level of Respondents

\begin{tabular}{|c|c|c|}
\hline Education level & Frequency & Percentage \\
\hline Primary level & 36 & $18 \%$ \\
\hline Secondary level & 4 & $2 \%$ \\
\hline University & 0 & - \\
\hline Not attended school & 152 & $76 \%$ \\
\hline NFE & 8 & $4 \%$ \\
\hline Total & $\mathbf{2 0 0}$ & $\mathbf{1 0 0 \%}$ \\
\hline
\end{tabular}

(Source: Household Interviews)

As can be seen from Figure 3 below, for those with basic primary education, male respondents were majority with 34 out of 36. Female respondents who indicated they have primary education were only two. This again just confirms the gender disparity in education that exists in the study area and the larger N.E. Kenya. 
International Journal of Science and Research (IJSR)

ISSN (Online): 2319-7064

Index Copernicus Value (2013): 6.14 | Impact Factor (2014): 5.611

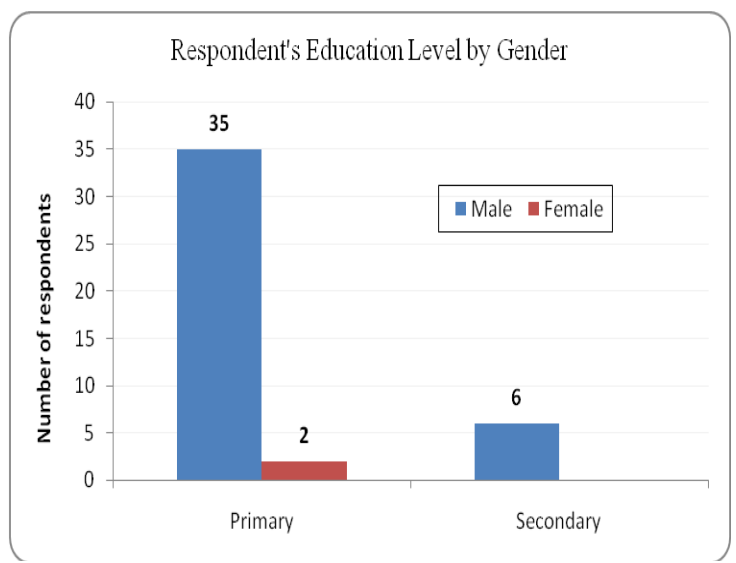

Figure 3: Respondents Education Level by Gender

\subsection{Changes in Coping Mechanisms against Drought Hazards}

\subsubsection{Drought Occurrences in the Study Area}

The study findings show that drought is one of the greatest risk factors facing community livelihoods in the study area. Key Informants recall several severe droughts that they have experienced. They identified 8 drought periods in the last two decades in the area (see the excerpt below). Since the effects of drought on people and their economy vary, the local communities describe each drought differently. Drought hazards are described with the events associated with them. For example, the drought of 1991-92 was named as the drought of Qamadi in Somali (wheat cereal), while the 1996 drought was described as Af-majir (twisting of the mouth in disbelief at the magnitude of the livestock loss). In each of these drought periods, respondents indicated that they have lost livestock. The magnitude of loss varies between droughts. In some drought years the loss is quite huge pushing some households out of the production system. A household would drop out of the system when they lose all their livestock or the number of livestock they remain with is uneconomical to herd. In this case they leave what remains with relatives and move to towns or rural centres. These households depend on food aid and casual labor in these towns. In some other drought years, the impact is less severe and the loss manageable. Below is an excerpt from a Focus Group Discussion.

\section{Drought year Events as narrated by Focus Group Discussions}

1991-1992: Qamadi -The drought period when the community first saw wheat cereals brought as food aid and the

entry of refugees from Somalia. The

community lost a lot of animals.

1994 Severe drought.

1996 Af-majiir - ,twisting of the mouth ${ }^{\text {ee }}$ in

disbelief at the magnitude of the loss of livestock caused by the

drought. The community lost a lot of

livestock. Households migrated to southern Somalia and Tana River.

Those who moved to Tana River district lost more animals than those who went to Southern Somalia
1997-98 El-Nino -resulted in the outbreak of Rift Valley Fever (RVF) disease. The community lost a lot of livestock

epidemic

particularly sheep and goats to the disease

2004-2006 - Damiija - widespread incidences of external parasites -ticks. Even the use of acaricides could not help. The worst

drought when most households lost their livestock. Herders migrated to Masalaani in Ijara district and Garbatulla

in Isiolo County.

2007 - Drought followed by the outbreak of the RVF when it rained.

2009 - Local drought.

2010-2011 - Very severe drought that has affected the whole of the country and the Horn of Africa region. Huge loss of livestock.

A glance at the excerpt above indicates that the area experiences drought every 2-3 years, which is an important characteristic of pastoral ecology. As reported in [2]: "Such droughts take several forms - localized, regional, and national - and vary enormously in intensity. Though unpredictable in any particular year for any specific location, pastoralists in Shanta-Abaq experienced five severe droughts, two mild droughts and an El-Nino in the last two decades.

\subsubsection{Early Warning and Drought Preparedness}

Early warning and drought management systems in Northern Kenya were first developed by the Drought Preparedness Intervention and Recovery Programme funded by the Dutch cooperation with the Kenyan Government between 1995 2000 [4]. In 2000, the Arid Land Resources Management Project (ALRMP) took over the management of the early warning system.

In the study area, there are field monitors who collect data on a monthly basis at household and community levels at one of the four warning stages of the drought- normal, alert, alarm, or emergency. In this way decision makers can immediately see whether an action is needed. If the system indicates an impending crisis, the drought monitoring component of the system is complemented by a quick mitigation intervention measures normally in terms of water tracking for the affected communities or localities. However, according to Key Informant interviews, the ALRMP functioned effectively in as much as it provided timely information to decision makers at district and national levels, but failed to trigger timely responses to drought in the district. As a result, it failed to reduce the vulnerability of pastoralists ${ }^{\text {ee }}$ household to drought hazards. [28] contends that lack of disaster preparedness has remained one of Kenyaes enduring development challenges for decades.

On the other hand, herders in the study area have been using their own traditional early-warning systems for decades [17]. They can read indicators of impending drought hazard with some degree of accuracy. However, despite the recurring drought in the environment and their ability to read some drought indicators, the community demonstrated lack of 


\section{International Journal of Science and Research (IJSR) \\ ISSN (Online): 2319-7064}

Index Copernicus Value (2013): 6.14 | Impact Factor (2014): 5.611

drought preparedness practices. They have become overly familiar with the yearly drought, yet do nothing to prepare for its eventual arrival. However, they employ dynamic coping mechanisms to the recurring hazards characteristic of their environment that can cushion them against the impact of the hazard. These coping mechanisms include herd size and diversity, mobility, social relations that they can fall back on during such crisis among others.

\subsubsection{Herd Size}

Respondents were asked to recall their herd histories from 2009 going back to 1990 in a five year step as follows: 2009, 2005, 2000, 1995 and 1990. Very few respondents could recall their herd sizes over the two decade period. This can be attributed first to changes in the household heads over the period. Some female household heads might not have joined the family for the last two decades, while others are too young to recall the numbers of the household herd for instance in 1990 or in 1995. In addition, many families were very emotional when it came to recalling their livestock numbers. One respondent had this to say:

„I was wealthy few years ago with over 200 heads today I am a destitute, I don't want to talk about it'. Abdullahi AliShanta-Abaq(Male, 38 years).

As displayed in Figure 4 below, the median number of livestock owned at household level (those who could recall their herd histories) for all species steadily declined from 1990 to 2009. For cattle, the median herd number in 1990 was 70 but this dropped to 10 in 2009 . There was a slight increase in 1995 due to favourable rains following the drought of 1994 in the area. As indicated in the excerpts on drought events in the study area, in 1996 there was a severe drought where the community lost a lot of livestock. As a result, there was a sharp decline in the median numbers of livestock owned per household.

The survey shows that for sheep, the median number owned in 1990 was 50 but there was rise in the median number till 1995 when it started to drop. Key Informants attributed this rise to two factors. One, during this period herders had started to shift to small stock after their cattle herds had started to dwindle. Second, the drop in cattle numbers meant reduced competition for the available grazing and browse resources. On the other hand, the median number of goats in 1990 was 80 but continued to drop over the years as displayed in Figure 4 below.

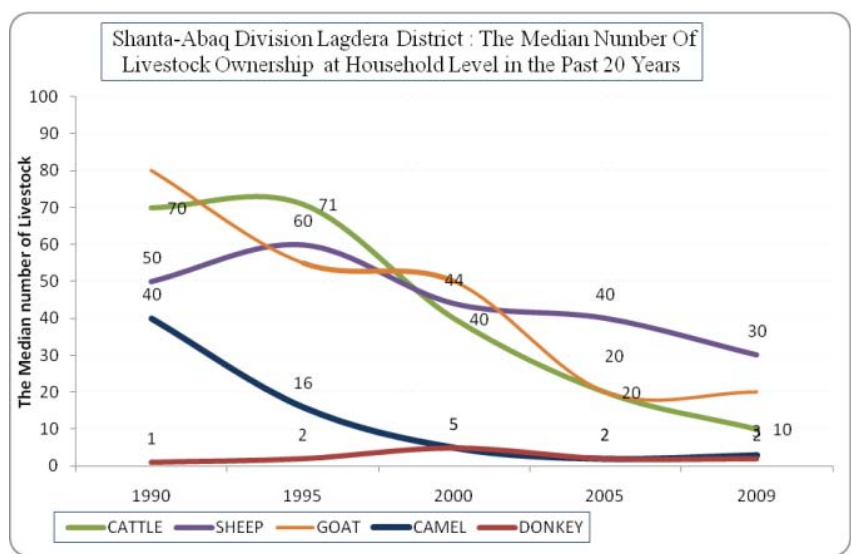

Figure 4: Median number of livestock owned in the past 20 years

The mean number of livestock owned over the last two decades also showed a marked decrease for each species of livestock as displayed in Figure 5 below. The species with the highest mean was cattle with 118 in 1990 but dropped to 6 in 2009. For sheep, the mean number in 1990 was 40 but there was marked increase in the first decade from 19902000. As explained by respondents above, this was due to the fact that most households started to switch to small stock as coping mechanisms to drought hazards in the area. As a result, they started to build their small stock herds. However, there was a sharp decrease in numbers in the next decade as displayed in Figure 5 below. This was due to a combination of factors. The major factor was the El-Nino rains 1996-97 that brought Rift Valley Fever disease that decimated small stock herds.

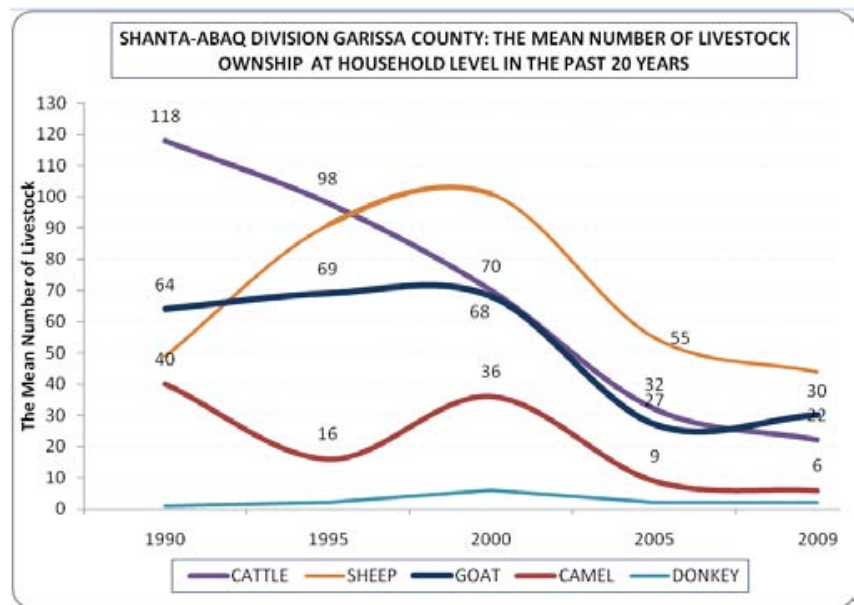

Figure 5: Mean number of livestock owned by households over the last two decades

\subsubsection{Herd Diversity}

As can be seen from Table 4 below, majority of the households (57\%) own two species; $31 \%$ own one species; $10 \%$ of the respondents own all the three species that include cattle, goats and sheep and camel and $2.5 \%$ of the respondents are destitute as they do not own any livestock or have any other form of income. This finding shows that households own a variety of livestock species to cope with climatic variability that is characteristic of their environment. Those households that own more than one species are less vulnerable to climatic shocks than those 


\section{International Journal of Science and Research (IJSR) \\ ISSN (Online): 2319-7064 \\ Index Copernicus Value (2013): 6.14 | Impact Factor (2014): 5.611}

households with only one species. The $31 \%$ of the households who rely only on one species are the most vulnerable group to climatic shocks and are less likely to cope with the recurring hazards that are characteristic of their environment.

Table 4: Livestock Species Diversity owned per Household

\begin{tabular}{|l|c|c|}
\hline Livestock Species Owned & Frequency & Percentage \\
\hline One species & 61 & $31 \%$ \\
\hline Two species & 114 & $57 \%$ \\
\hline Three species & 20 & $10 \%$ \\
\hline Nolivestock & 5 & $2.5 \%$ \\
\hline Total & $\mathbf{2 0 0}$ & $\mathbf{1 0 0} \%$ \\
\hline
\end{tabular}

(Source: Household interviews)

According to respondents, the most popular combination of species owned were cattle, sheep and goats with $82 \%$ of those with two livestock species owning sheep, goats and cattle. Only $1.8 \%$ of the respondents own a combination of cattle and camel while $16 \%$ own camel, sheep and goats. Of those who rely on one species, $85 \%$ of them own sheep and goats, $13 \%$ own cattle only while $1.6 \%$ rely on camel as their only livelihood assets. However, household herd size among this group is quite low with average households owning six heads of camel.

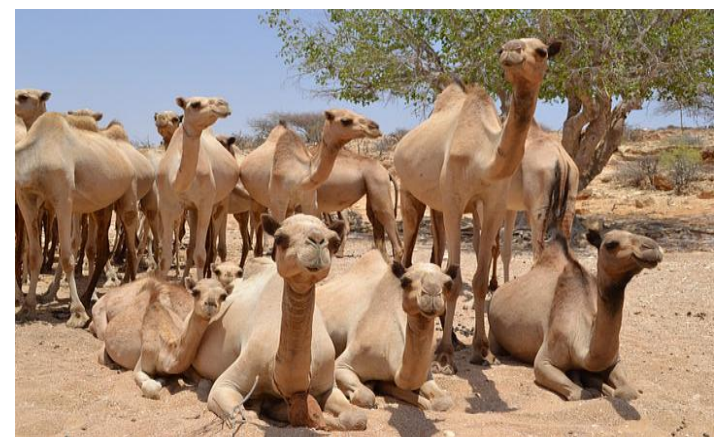

Figure 6: Photo of a camel herd in Shanta-Abaq location

The result of the study show that household species composition has significantly changed over the last two decades. While in 1990 most households relied on cattle as their main livelihood asset, the picture is quite different today (FGD). Households have switched to sheep and goats over the years. There are several possible explanations for this result. First, sheep and goats are like liquid cash. They can easily be sold or slaughtered to meet household needs. Second, sheep and goats are easier to manage in terms of feed and water requirement and can be kept around trading centers; giving room to poor households to engage in other casual work. On the other hand; cattle requires to be moved to distant grazing zones in search of better pasture and water resources and require higher level of herding and management.

\subsubsection{Social Support}

Evidence from this study demonstrates that the spirit of social support is still strong among the community but the ability to support the poor members is weak. This can be attributed to the growing level of poverty in the community. Over $72 \%$ of the households studied are poor having lost their livestock to drought hazards over the years. This high poverty level has therefore constrained householdse ${ }^{e e}$ ability to support each other during crisis. A participant in a Focus Group Discussion stated a Somali proverb ,Laba qaawan ismaqaado' meaning two poor individuals or families cannot support each other even if they wish to do so.

According to respondents, when compared with 1990, social support has changed. In the past households could support each other with livestock. For instance when a household loses its herd to drought hazard or to raids or disease epidemic, the kinship network would mobilize support and provide the household with some breeding herd but this is no longer the case. Major support is now in terms of credit, food aid and labor support. This finding shows that when a household loses its herd either to drought or other hazards, it will most likely be forced to drop out of the production system as the community mechanisms of sustaining poor households in the system have broken down. The finding further indicates that there is need for government to look at formal safety net assistance such as cash transfers to support poor families who have dropped out of the pastoralist production system.

\subsubsection{Household Spatial Mobility}

Spatial mobility is crucial for the survival of the herds during crisis and a key feature of the production system. In normal years herders migrate within their district territory as illustrated in Figure 11 below. The frequency of these movements are influenced by many factors including availability of water and pasture, existence of external parasites and even security. When asked how often they migrate in a normal year, 131 respondents responded. Out of those who responded, 78.6 indicated that they move once a month, $5.3 \%$ indicated their movements are bi-monthly while $10.7 \%$ indicated they move on quarterly basis.

Table 5: Herders Frequency of Movement

\begin{tabular}{|c|c|c|}
\hline Movements & Frequency & Percent \\
\hline Once a month & 103 & $78.60 \%$ \\
\hline Bi-monthly & 7 & $5.30 \%$ \\
\hline Quarterly & 14 & $10.70 \%$ \\
\hline Other (more than 5 times & 7 & $5.30 \%$ \\
\hline Total & $\mathbf{1 3 1}$ & $\mathbf{1 0 0}$ \\
\hline
\end{tabular}

(Source: Household interviews)

When the present movements were compared with those of 1990s, the majority of respondents said that the frequency of mobility has increased over the past 20 years. Out of the total sample, $66 \%$ of the respondents indicated that they either move very often or often as compared to the past. The most probable explanation for this is the changing climatic condition that has become worse and resources such as pastures and water quite limited making movements quite frequent.

Table 6: Household Mobility in the past 29 years

\begin{tabular}{|c|c|c|}
\hline Household Mobility & Frequency & Percent \\
\hline Very often & 75 & $37.50 \%$ \\
\hline Often & 59 & $29.50 \%$ \\
\hline Uncertain & 34 & $17 \%$ \\
\hline Limited & 12 & $6 \%$ \\
\hline Unlimited & 20 & $10 \%$ \\
\hline Total & $\mathbf{2 0 0}$ & $\mathbf{1 0 0}$ \\
\hline
\end{tabular}




\section{International Journal of Science and Research (IJSR) \\ ISSN (Online): 2319-7064}

Index Copernicus Value (2013): 6.14 | Impact Factor (2014): 5.611

(Source: Household interviews)

In order to cope with climatic variability, households in the study area are forced to move their livestock across a vast rangeland sometimes out of their traditional territory into completely unfamiliar areas of other clans. According to participants in a Focus Group Discussion, it is not only the depletion of pastures and water that trigger a movement but a host of other factors that ensure the survival of the herders and their stock. Participants in a Focus Group Discussion looked at the merit of each location where they normally migrate as indicated in the excerpt below.

\section{Location -Tana River District}

\section{Merits}

- Receives slightly more rains than Shanta-Abaq.

- The district has abundant browse for camel and goats and also for cattle during drought periods.

- Source of water is the Tana River so it is free unlike the study area where households pay for water from boreholes during dry spells. This is a relive to poor households who cannot afford the fees charged at the boreholes.

- Prices of livestock are better than in the study area due to the proximity to secondary livestock markets.

- Essential food stuff are cheaper in the district. For instance the participants stated that $1 \mathrm{~kg}$ of sugar costs about 150 Kenya shillings in Shanta-Abaq while it costs about 100 Kenya shillings in Tana River

\section{Location: Isiolo District}

- The district has community conservancy particularly around Merti area that generates some income both for the local Authority and the community. As a result, there are good pastures for livestock.

- Adequate water availability, there are springs that provide for both livestock and humans. However, there are defined by-laws for the management of water and grazing resources. The pastoralists from Shanta-Abaq are unable to abide by these by-laws which eventually lead to friction with the host community and at times results in conflict.

- Prices of livestock are high compared to Shanta-Abaq

- Food and non-food items are also cheaper.

\section{Location: Garissa}

- The Tana River passes through this district and riverine pastures have provided critical grazing for livestock during drought periods.

- There is secondary livestock market in Garissa thus the prices of livestock are slightly higher than Shanta-Abaq.

\section{Location: Southern Somalia}

- Receives the „Hagaa ${ }^{e e}$ ( light showers in July/August) rainfall

- The region has diverse vegetation and produces pastures

- Livestock produces more milk and households normally make ghee and sale in Garissa markets when they return.

- Food stuff is also very cheap in Somalia due to low taxation.

During drought hazards when pastures in their district are depleted, households in the study area migrate to the above regions to ensure survival of their herds and households Each household makes its own decision on whether or not to migrate and to which region. According to Focus Group Discussions when drought strikes herders start to collect information on possible areas to migrate to. They try to establish status of grazing resources in the different neighboring regions, access to water, presence of external parasites such as the tsetse fly, the security of the area and the relationship between their community and the host community and livestock prices. This information is then used to assess potential risks and the opportunities that exist. Once this is done, individual households start to engage in self-assessment to determine factors that can constrain them and resources that are available to them including labor, kinship network support and even the cost of the movement. They would also consult widely within their kinship networks and the larger community. Herders would seek advice and the thinking of others or the decisions that have been made by others, which can inform their decision.

Respondents were asked to rate the relationship between their community and the neighboring communities in Isiolo, Tana River, Lower Juba in Southern Somalia as illustrated in Figure 7 below. On the relationship between Shanta-Abaq community and their neighboring community in Isiolo district, $63 \%$ of the respondents indicated that the relationship was friendly while $33 \%$ thought it was tense, and only $4 \%$ were not sure.

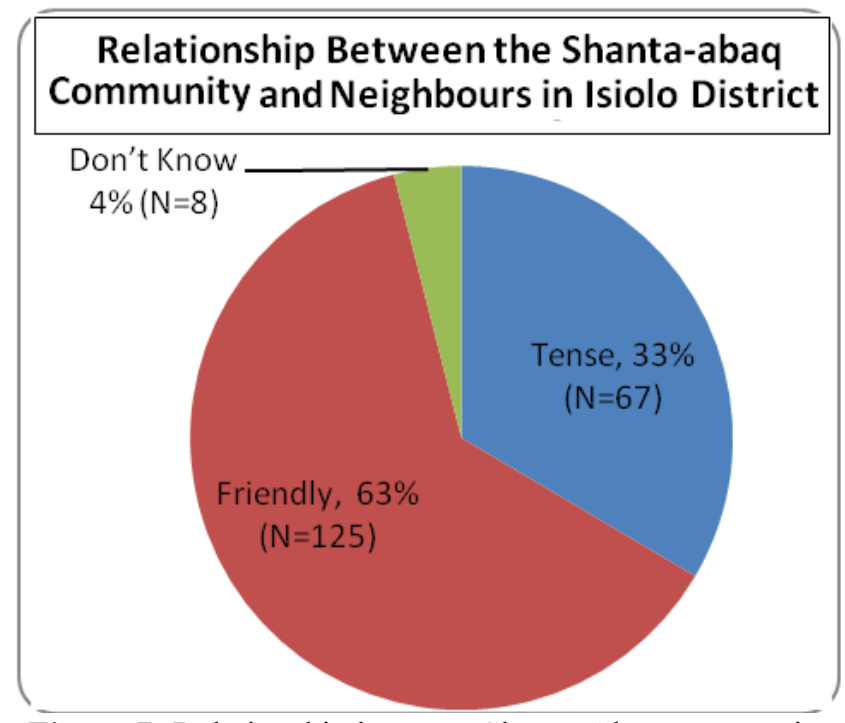

Figure 7: Relationship between Shanta-Abaq community and Isiolo Community

When the above responses were cross tabulated with sex the results were engendered. More female (19.8\%) than male $(15.1 \%)$ respondents indicated that their community relationship with the neighbouring community in Isiolo district was tense. For those respondents who indicated that their community relationship with Isiolo community was friendly, majority, $43.8 \%$ were males while less than half of this number were females. 


\section{International Journal of Science and Research (IJSR) \\ ISSN (Online): 2319-7064}

Index Copernicus Value (2013): 6.14 | Impact Factor (2014): 5.611

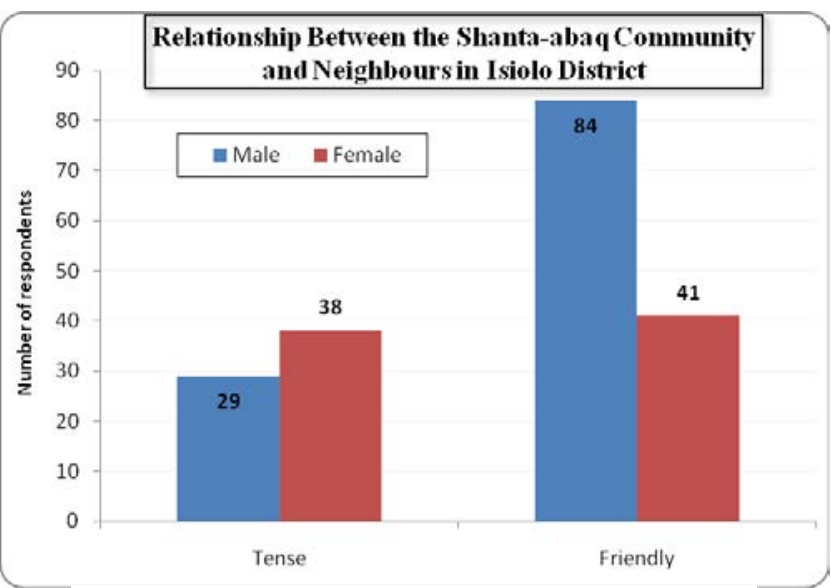

Figure 8: Relationship between the Shanta-Abaq community and neighbours in Isiolo District

When it came to the relationship between their community and those in Lower Juba of southern Somalia, 52\% felt that the relationship is friendly while $42 \%$ said it was tense at the time of the study.

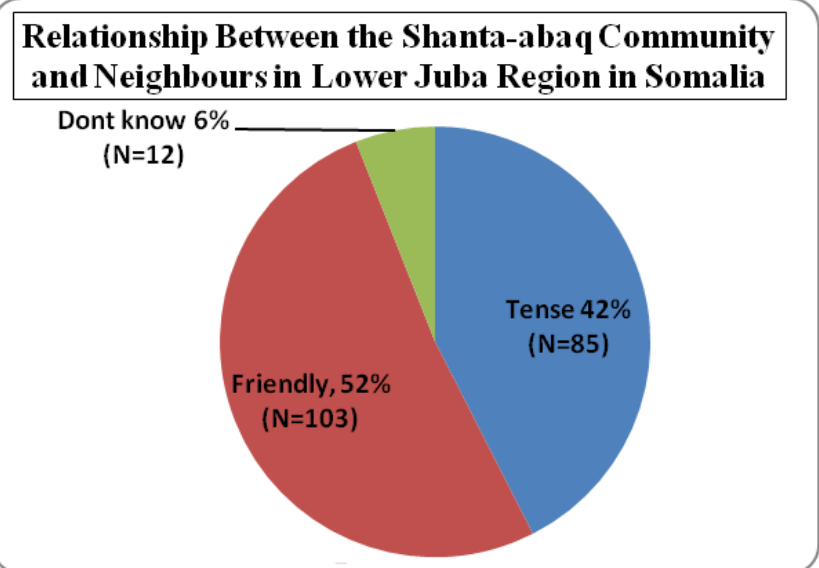

Figure 9: Relationship between Shanta-Abaq and those of Lower Juba in Southern Somalia

As illustrated in Table 7 below, when the responses were cross tabulated with sex, it was also engendered. Out of those respondents who felt that their community relationship with that of Lower Juba was tense, females were the majority. Out of the total respondents, 46 female respondents representing $24.5 \%$ indicated that the relationship was tense while for males 39 respondents representing $20.7 \%$ said their relation with their neighbors in Lower Juba of southern Somalia was tense. For those who indicated their community relationship with those of Lower Juba was friendly, there were more males than females.

Table 7: Relation with Lower Juba cross-tabulated with sex

Relation with Lower Juba

\begin{tabular}{|c|c|c|c|c|c|}
\hline \multirow[b]{2}{*}{ Sex HHH } & \multirow[b]{2}{*}{ Male } & \multirow[b]{2}{*}{$\begin{array}{c}\text { Count } \\
\% \text { of total }\end{array}$} & Tense & Friendly & Total \\
\hline & & & $\begin{array}{l}39 \\
20.7 \%\end{array}$ & $\begin{array}{l}71 \\
37.8 \%\end{array}$ & $\begin{array}{l}110 \\
58.5 \%\end{array}$ \\
\hline \multirow[b]{2}{*}{ Total } & Fen & $\begin{array}{l}\text { count } \\
\% \text { of total }\end{array}$ & $\begin{array}{l}46 \\
24.5 \%\end{array}$ & $\begin{array}{c}32 \\
17.0 \%\end{array}$ & $\begin{array}{l}78 \\
41.5 \%\end{array}$ \\
\hline & & $\begin{array}{c}\text { count } \\
\% \text { of total }\end{array}$ & $\begin{array}{c}85 \\
45.2 \% \\
\end{array}$ & $\begin{array}{c}103 \\
54.8 \% \\
\end{array}$ & $\begin{array}{l}188 \\
100 \% \\
\end{array}$ \\
\hline
\end{tabular}

According to Key Informants, advice of elders is crucial at this point and references are made to past migrations to these regions and what their experiences were at that given time. They would then develop a strategy, which may include: separating the family from the herds and moving satellite herds with male herders to the distant regions while the families would remain behind to benefit from relief food. It could also include sharing labor and costs within the kinship networks. Those households who own two species could sometimes separate and send camels to one region such as the Tana River district and move cattle across the border to Somalia to minimize risks and maximize on the use of vegetation.
Respondents indicated that a set of factors constrain their mobility to neighboring regions. As illustrated in Figure 10 below, $66 \%$ of the respondents indicated that they are constrained by children in school, $62 \%$ are constrained by the fear of being attacked by rival clans, a household may not want to move away from where they can access food aid $(56 \%)$; may not be able to afford the cost of the movement $(51 \%), 34 \%$ felt that they were constrained by lack of the required labor from migrating to distant regions during crisis. A household may face a combination of these factors at any point in time. 


\section{International Journal of Science and Research (IJSR) \\ ISSN (Online): 2319-7064}

Index Copernicus Value (2013): 6.14 | Impact Factor (2014): 5.611

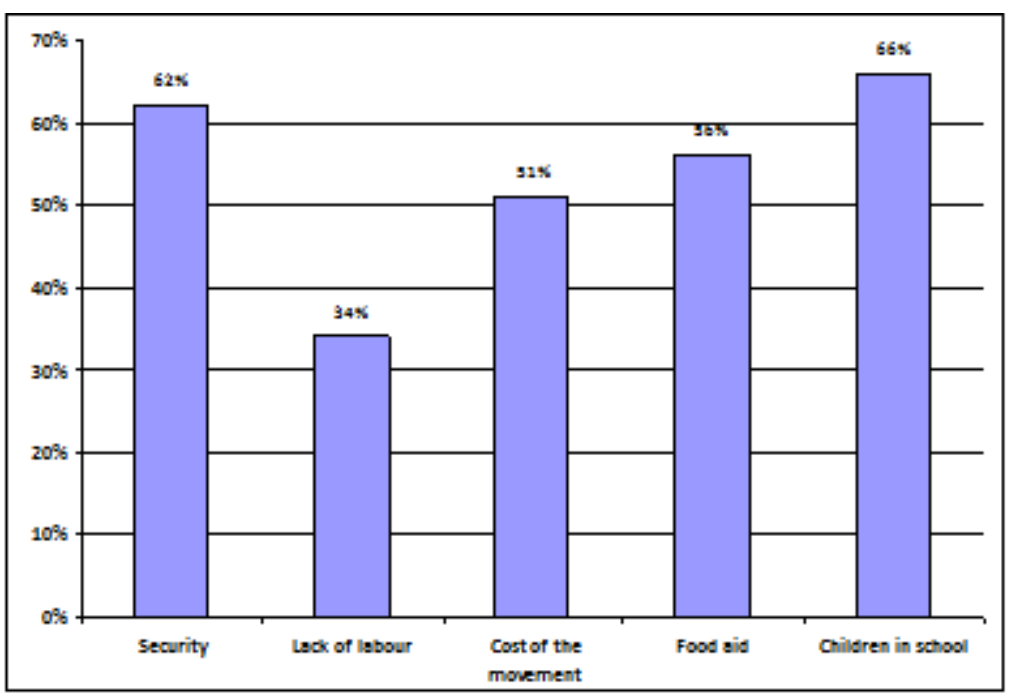

Figure 10: Factors constraining household migration to distant regions (Source: Household Interviews)

Respondents also provided information on mobility patterns during drought hazards over the last two decades in the study area (see map below). During normal years movement is greatly within their territorial boundary as indicated by Figure 11 below. But when drought hits their territory and grazing resources are depleted, herders are forced to move to distant regions to avoid the starvation of their livestock. Common destinations include Lower Juba in Southern Somalia, neighbouring districts of Isiolo, Tana River and Ijara.

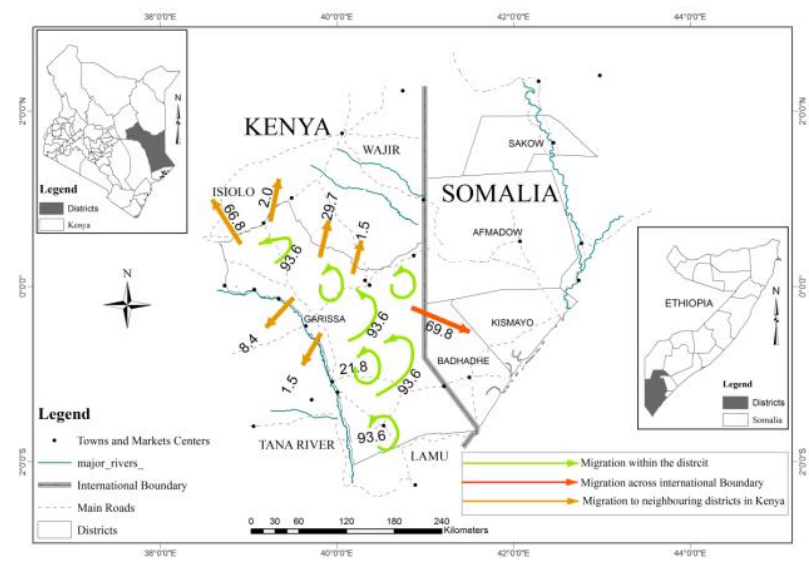

Figure 11: Map representing the spatial movements of the herders in the study area (Source: Household interviews)

\subsubsection{Supplementary Feeding During Crisis}

Key Informants indicated that herders are increasingly providing supplementary feeds to few numbers of breeding stock to ensure their survival during drought. They feed their stock with cereals such as maize, millet and sorghum. Relief supplies provide vital sources of these feeds. Participants in Focus Group Discussions corroborated this evidence and added that households are willing to invest in livestock feed during crises but availability and the quality is what is limiting such an investment. The Government had provided some fodder for livestock in the last two drought periods but the effort is quite negligible. This finding shows that pastoralists are developing new coping mechanisms in response to the cyclic drought hazards in their environment, and illustrates that efforts to promote the development and access to commercial livestock feeds need to be stepped up. There is a huge potential for fodder production along the River Tana but this has not yet been tapped. This can be part of a drought preparedness strategy for the County and would go a long way to save thousands of livestock from starvation during drought crises.

\subsection{The Impact of Conflict on Spatial Mobility in the Study Area}

Violent conflicts involving pastoralists have become widespread and increasingly severe in the North Rift and North Eastern regions of Kenya. A study conducted by [15] pointed out that the major causes of conflict among the pastoralists include but are not limited to intensified cattle rustling, proliferation of illicit arms, inadequate policing and state security arrangements, diminishing role of traditional governance systems, competition over control and access to natural resources such as pasture and water, land issues, political incitements, ethnocentrism, and increasing levels of poverty and idleness amongst the youth.

Over the last two decades, herders in the study area were faced with several conflicts with their neighbors that have had a profound impact on their livelihoods. To cope with the recurring drought hazards in the region, herders need to move their livestock across the rangeland of patchily distributed resources, highly influenced by low, variable, and unpredictable rainfall. They need to access dry season grazing areas found along rivers or in territories of other communities. These not only provide critical grazing when resources in their territory have been depleted, but are part of strategies to allow wet season grazing areas to rest. It is also important for animal husbandry including the breaking of livestock-parasite cycles. Respondents outlined three major conflicts with their neighbors that really influenced their grazing pattern over the last two decades as outlined below.

\subsubsection{1 - Somalia Civil War}

In 1991, a civil war broke out in Somalia after a coalition of clan-based armed opposition groups ousted the nation's longstanding military government led by General Siad 


\section{International Journal of Science and Research (IJSR) \\ ISSN (Online): 2319-7064 \\ Index Copernicus Value (2013): 6.14 | Impact Factor (2014): 5.611}

Barre. Various factions started competing for the power vacuum that followed. It is estimated that 1.5 million people fled the country to seek asylum in neighboring countries such as Kenya, Ethiopia and in other countries abroad while 2.5 million were internally displaced.

During the period 1991-1992, drought, the destruction of social and economic infrastructure, clan conflict and the disruption of food supplies caused a famine in which an estimated 250,000 people died. Those who suffered most were the politically marginalized and poorly armed riverine and inter-riverine communities in southern Somalia who suffered waves of invasions from better-armed militia from the major clans.

Lower Juba region of southern Somalia has been a traditional dry season grazing zone for pastoralists from North-east Kenya due to its better rainfall regime and abundant grazing, browsing and water resources. However, the collapse of the central government in Somalia and the clan conflicts that followed for the last two decades has impacted negatively on this long-standing grazing pattern.

Key Informants narrated how the conflict between the Aulihan and the Marehan clan groups in Gedo region of Somalia displaced thousands of the Aulihan clan out of their traditional grazing territory into Lagdera region of Garissa County. These refugees brought with them their livestock thereby, increasing the livestock number in the region including the study area.

A number of respondents indicated that though they move to some parts of lower Juba of southern Somalia, the frequency and preference for the region has significantly reduced due to the breakdown of law and order in the country. Most respondents indicated that the security of their herds is important in the choice of where they migrate to during periods of crisis. As indicated in Figure 10, $62 \%$ of the sampled households indicated that the fear of insecurity may prevent their households from migrating to distant regions during crisis.

\subsubsection{Aulihan-Boran Conflict}

Isiolo County borders the greater Garissa County to the North West and is one of the counties in the former Eastern province of Kenya. The County is inhabited by the Boran ethnic group who are pastoralist and predominantly keep cattle. The study findings show that Isiolo County has been a destination of choice for herders from Shanta-Abaq division during drought crisis when pastures in their territory are depleted. Through the process of reciprocity herders had over the years established relationships that allow access to grazing in their neighbors territories including Isiolo.

According to respondents, Isiolo County has less livestock concentration compared to their area, better quality pastures as a result of more defined wet and dry season grazing patterns, fewer areas that are denuded (Haluf in Somali) and fresh and quality grazing resources ( $o s o b$ in Somali). The Boran still practice their traditional grazing management with defined by-laws and all herders who move into the region are expected to abide by these rules. However, respondents indicated that the Somali herders find it hard to abide by these rules, which eventually trigger conflict with their neighbors. [16] contends that Boran pastoralists traditionally reserve some areas based on wet and dry season grazing systems but Somali herders violate this resource arrangement. He further contends that camel graze in drought fall back areas of the Waso Boran that resulted in tension and conflict. The other underlying cause of friction is the encroachment on pastoralists ${ }^{\text {ee }}$ lands by wildlife conservancy. The government established some community conservancy particularly around Merti area that generates some income both for the local Authority and the community. This resulted in increased competition for grazing between wildlife and humans and between communities. As a result, a bitter conflict broke out between the Boran and Somali communities in 1992 and went on for almost a decade. A peace process was eventually negotiated between the communities and the famous Modogashe declaration was signed in 2001 .

\subsubsection{Aulihan-Abudwak Conflict}

The larger Garissa is currently administered under three districts namely Garissa, Lagdera and Fafi with a total of 12 divisions. It is home to two major sub-clan groups of the Ogaden clan of the Somali ethnic group. These are Abudwak and Aulihan sub-clans. Each of these sub-clans occupies and identifies itself with a given traditional grazing territory. The Aulihan occupy Lagdera district while Abudwak occupy Garissa and Fafi districts.

In 1999 a bitter conflict broke out between the two communities across the Garissa and Lagdera border. According to Key Informants, the cause of the conflict between these two communities has to do with competition over control and access to natural resources such as pastures, water and land issues. One key resource in the County is the River Tana that passes along the border between Garissa and Tana River County. Apart from providing permanent water for livestock; the river also provides vital dry season grazing resources for pastoralists. It is access to and control over this vital resource that triggered the conflict between the two sub-clan families. A peace accord was signed between the two communities in April 2000 that sets out the overall issues that threaten to erupt in conflict. One provision in the agreement was that the Aulihan community stays away from the River Tana, which the Abudwak community claims as their resource by virtue of its location.

\subsubsection{The implication of the Modogashe declaration and Garissa Peace Accord}

The Modogashe Declaration and the Garissa community peace accord both set out the overall issues that threaten to erupt in conflict, such as cattle rustling, disputed use of pasture and water sources, and trafficking of illegal firearms. Its provisions further spell out ground rules to solve each specific problem. For example clause 10-13 of the declaration deals with the use of pasture and water and establishes that a community in need of pasture and water in other communities territory must seek prior consent from the respective elders and chiefs if they wish to migrate to that area; and that if granted the decisions must be clearly documented; and that they must respect the existing traditional resource use mechanisms in the host community territory; and that they must return to their home district at 


\section{International Journal of Science and Research (IJSR) \\ ISSN (Online): 2319-7064 \\ Index Copernicus Value (2013): 6.14 | Impact Factor (2014): 5.611}

the end of a drought. This provision was intended to stop the conflicts over pasture and water at the Garissa-Isiolo district boundaries. Interestingly, it reintroduces a customary usage system, under which people need to seek permission to migrate to an area that is claimed by a different group. It contradicts official law, which allows anyone to move freely within the country and which would not acknowledge such customary land claims. It has as a result denied communities access to grazing resources in neighbouring communities as they need prior permission to migrate to other territories. It locks out the herders from the study area out of vital dry season grazing resources. A Key Informant had this to say:

„Nowadays we cannot migrate to Isiolo district because of hostilities between the Boran and Somali communities, the 1992 conflict has locked us out of the district' -Abdikadir Amey -Shanta-Abaq, (Male, 43years).

\subsubsection{The Government Policy of Sedentarization}

According to Key Informants, the seeds of sedentarization were originated by the colonial government and reemphasized by the new independent Kenyan government at independence in response to the clamour for secession by the people of the former Northern Frontier Districts (NFD). In a run up to Kenyan independence, the people of NFD rallying behind Northern People"s Progressive Party (NPPP) demanded for secession having been politically and economically marginalized by the colonial administration. However, in 1963, Duncan Sandys, the colonial secretary announced that the NFD will remain part of Kenyaes regional constitution. This was despite the findings of a commission of inquiry which reported that the Somali and other Muslim minorities unanimously favored secession [32]. Frustrated and antagonized; the people of former NFD waged a civil war popularly known as ,Shifta ware calling for recognition of their rights to self -determination and unity with the Somali Republic. This war continued until 1968 when diplomatic relations between Kenyan and Somalia governments were re-established and ended the technical and logistical support for the rebels.

In order to contain this war the newly independent Kenyan government came up with a range of measures that had a profound impact on the socio-economic conditions of the people of NFD as well as shaped the development policy in the decades that followed. One such measure was the villagization of the people of NFD. The intention was to get all people living in the countryside to the villages where the security forces could easily control them. This resulted in movement and grazing restrictions. The security forces felt that it was difficult to track down bandits as they were aided by mobile pastoralists. As a result, the idea of moving people to the villages in order to cut off that support was borne. Key respondents felt that the counter insurgency measures were directed not only at the secessioniste fighters but also at the pastoralists more broadly.

In the decades after Kenyan independence, the desire to settle the pastoralists continued to shape the development policy in the region. [32] contends that the Kenya government discovered a powerful political weapon in the shifta war that provided a pretext for forcing social and political change in the NFD region. A Key Informant had this to say:

„In 1991-92 the theme of the agricultural shows in North eastern province held in Garissa was -Kusimamisha Maisha ya Kuhamahama (stopping nomadic lifestyle)' - Ibrahim Hussein Garissa,(Male, 52 years).

In early 1970 s, the government started the Kenya Livestock Development Program (KLDP) that was based on the policy to change the nomadic lifestyle. The project established grazing blocks in the region and constructed numerous water pans and drilled boreholes particularly along the Merti aquifer. Subsequently, these sources of permanent water attracted settlements as envisaged by the policy planners. Over the years the settlements have grown bigger as the government provided services such as schools, health centers and relief food to the inhabitants who were largely pastoralist dropouts.

In $1980^{\circ} \mathrm{s}$ and $1990^{\circ} \mathrm{s}$, the government created administrative units around all water points in the region. [30] contend that in Wajir County as a rule, the government would create a location and appoint a chief. The chief so appointed would persuade his community to settle in the locality usually under pressure from the district administration and the local political leadership without any due regard for its impact on the environment and the traditional land use system. The trend was similar in the study area. This led to mushrooming of settlements in the region.

Shanta-Abaq division has grown over the last two decades from a wet season grazing area to a full division with five locations that are fully settled. Before 1981, the area was a wet season grazing land for the local pastoralists ${ }^{\text {ee }}$ population. With its open and expansive grassland, the area provided key wet season grazing resources for herders in the district. In 1981, the first borehole was dug and the government immediately appointed a chief. A settlement began that expanded rapidly over the years.

Participants in Focus Group Discussions were in consensus that their traditional patterns of wet and dry season grazing and drought fall back areas have been disrupted by the mushrooming of settlements in the district and the region at large. The number of settlements have increased over the last two decades without due regard for the pastoralist mobility patterns. These settlements have come with water development particularly in what used to be the dry season grazing areas. This finding shows that the disruption of the crucial traditional grazing pattern has weakened the drought coping mechanisms of the pastoralists in the study area thereby increasing their vulnerability.

\section{Conclusion}

It is evident that the key coping mechanisms households use to protect their livelihoods against climatic variability has been weakened due to negative policies and conflict with neighboring communities. Households have tried to diversify their livestock species to cope with climatic variability but mean household herd size for all species are quite low. Therefore the ability to mitigate against risks are 


\section{International Journal of Science and Research (IJSR) \\ ISSN (Online): 2319-7064 \\ Index Copernicus Value (2013): 6.14 | Impact Factor (2014): 5.611}

limited. Herders ${ }^{e e}$ spatial mobility that is critical for their production system has been severely constrained by three key conflicts that have happened in the area over the last two decades. These conflicts have constrained herder mobility and limited their access to vital grazing resources when conditions in their territory are poor making them more vulnerable to hazard triggered crisis. Evidence from the study also demonstrates that the spirit of social support is still strong among the community but the ability to support each other is weak. At the same time the nature of the support has changed over the years. While in 1990 families could support each other with livestock, currently the major support is in terms of credit, food aid and labor. The implication of this is that when a household losses its herd either to drought or other hazards, it will be forced to drop out of the production system.

Finally, the conditions of households in the Shanta-Abaq division over the last five years have been deteriorating and they no longer feel confident that they can cope with the recurring hazards that are characteristic of their environment. This is an indication that their vulnerability to drought hazards is increasing and their livestock based livelihood is facing a threat from natural hazards such as drought.

\section{Recommendations}

This study has shed some light on the status of pastoralism in the study area. The growing vulnerability of the livelihood system is evident and the conditions of those who depend on the livelihood system are highlighted. There is, therefore, a definite need to find ways of protecting this crucial production system that feeds millions of people and makes a significant contribution to the national Gross Domestic Product (GDP). The study makes the following recommendations:

a) Addressing the root causes of pastoralist vulnerability:

Government and development partners need to address the root causes of the pastoralist livelihood vulnerability. Past efforts to tackle pastoralist challenges have focused primarily on relief and emergency interventions but failed to focus on the policy frameworks that have continued to undermine the pastoralist production system. These external factors that continue to undermine the adaptive capacity of pastoralists to climatic variations need to be addressed.

b) Spatial mobility. Spatial mobility to exploit scare resources over a wide geographic area is one of the key pillars of pastoralism. From the study area, herders migrate to southern Somalia and to neighbouring districts of Isiolo, Tana River, Ijara and Garissa but these crucial migratory routes are threatened by conflict and settlements. There is need to protect pastoralist migratory routes across counties by supporting peace building initiatives between communities.

c) Acknowledge the drop out from the pastoralist production system and support those affected to engage in alternative livelihoods. This calls for investment in the arid and semi-arid regions of the country.

d) Develop and support a community based drought preparedness strategy that aims to protect the livelihood system from the impact of the recurring drought hazards in the region. This should exploit the potential for fodder production along the Tana River. Early warning systems can be used to trigger production of early maturing fodder species such as Sudan and Columbus grasses and a link developed between the pastoralist and the riverine farmers in Garissa County.

\section{References}

[1] A. Aboud, Range Management Extension Services on Pastoral Societies of Kenya, Ohio State University, Columbus, 1982.

[2] A. Aboud, F. Abdikadir, M. Hileman, "Pastoralists Lifestyles and Developmental Paradigms: The Contradictions and Conflicts," In Proceedings of the Kenya Pastoralist Forum, 1996.

[3] A. Ahmed, M. Salih, "Post Drought Recovery Strategies among Pastoral Households in the Horn of Africa: A Review," Development Research Report Series No. 3, OSSREA, 2004.

[4] Y. Akilu, M. Wekesa, "Livestock and Livelihoods in Emergencies: Lessons Learnt from the 1999-2001 Emergency Response in the Pastoralist Sector in Kenya," Pastoralists Livelihood Initiatives Policy Brief No. 2, Feinstein International Famine Centre, Addis Ababa, Ethiopia, 2001

[5] M. Babikker, S. Pantuliano, "Addressing Chronic Livelihoods Vulnerability in Red Sea State, Sudan," Report to OXFAM GB, Humanitarian Policy Group, ODI, London, 2006.

[6] M. Bassi, The Making of Unsustainable Livelihoods: An on-going tragedy in the Ethiopia dry lands, Addis Ababa, 2002.

[7] R. Bench, You can 't go home again: Pastoralism in the new millennium, ODI, London. 2001.

[8] D. Campbell, "Response to drought among farmers and herders in southern Kajiado District, Kenya: A comparison of 1972-1976 and 1994-95," Human Ecology, 27(3), pp. 377-416, 1999.

[9] T. Cannon, "Vulnerability Analysis and Disasters," in Floods, D Parker (ed), Routledge, London, 2001.

[10] T. Cannon, J. Twigg, J. Rowell, Social Vulnerability, Sustainable Livelihoods and Disasters, DFID, London, 2004.

[11]W. Chinogwenya, M. Hobson, Getting it Right: Understanding Livelihoods to Reduce the Vulnerability of Pastoral Communities, ODI, Humanitarian Policy Group, London, 2009.

[12] C. Del Nino, A. Marini, "Household's Vulnerability to Shocks in Zambia," SP Discussion Paper No. 0536, 2005.

[13]S. Devereux, "Vulnerable Livelihoods in Somali Region, Ethiopia," Research Report 57, Institute of Development Studies, London, 2006.

[14] S. Eriksen, J. Lind, The Impacts of Conflicts on Household Vulnerability to Climatic Stress: Evidence from Turkana and Kitui Districts in Kenya, Nairobi, 2005.

[15]ITGD-EA, Conflict in Northern Kenya. A Focus on the Internally Displaced Victims in Northern Kenya, DTP Martin Karimi Publishers, Nairobi, 2003. 


\section{International Journal of Science and Research (IJSR) \\ ISSN (Online): 2319-7064 \\ Index Copernicus Value (2013): 6.14 | Impact Factor (2014): 5.611}

[16] A. Jillo, Assessment of Pastoral Resource Management Risks among Waso Boran, Egerton University, Njoro, Kenya, 2011.

[17] W. Luseno, J. Mcpeak, C. Barret, P. Little, G. Gebru, "Assessing the Value of Climate Forecast Information for Pastoralists: Evidence from Southern Ethiopia and Northern Kenya," World Development, 31 (9), 2003.

[18] J. McCabe, "Success and Failure: The Breakdown of Traditional Drought Coping Institutions among the Pastoralist Turkana of Kenya," Journal of Asia and African Studies, XXV (3-4), p. 146, 1990.

[19] O.M. Mugenda, A. G. Mugenda. Research methods: Qualitative \& Quantitative approaches, Nairobi-Kenya. Africa centre for technology studies. 1999.

[20]M. Niamir, "Traditional African Range Management Techniques: Implications for Rangeland Development," in Community Forestry: Herders Decision-making in Natural Resources Management in Arid and Semi-Arid Africa, Community Forestry Unit, FODP, FAO, Rome, 1990.

[21] M. Niamir-Fuller, (ed.), Managing mobility in African Rangelands; the legitimization of transhumance, FAO/Beijer IIEE, Rome/Stockholm, 1999.

[22] M. Nori, J. Switzer, A. Crawford, Herding on the Brink: Towards a Global Survey of Pastoral Communities and Conflict, An Occasional Working Paper from IUCN Commission on Environment, Economic and Social Policy, International Institute for Sustainable Development, 2004.

[23] G. Oba, "The Importance of Pastoralistse Indigenous Coping Strategies for Planning Drought Management in the Arid Zone of Kenya," Nomadic People NS, 5 (1), 2001.

[24]E. Onsomu, G. Kosimbei, M. Ngware, "Impact of gender and socio-economic factors on primary education performance in Kenya: An empirical analysis," KIPPRA Discussion Paper Number 56, Kenya Institute for Public Policy Research and Analysis, Nairobi, 2006.

[25]C. Pratt, "Traditional Early Warning Systems and Coping Strategies for Drought Among Pastoralist Communities, Northeastern Province-Kenya," Working paper No. 8, Feinstein International Famine Centre, 2002.

[26] J. Pretty, D. Smith, "Social Capital in Biodiversity Conservation and Management," Conservation Biology, 18 (3), 2003.

[27] Save the Children-UK, Vulnerability and Dependency in 4 Livelihoods Zones of North Eastern Province, Kenya: Assessed Using the Household Economy Approach (HEA), SC/UK, Nairobi, 2007.

[28] C. Suda, "Natural Disaster Preparedness, Environmental Degradation and Sustainable Development in Kenya," African Study Monographs, 21(3), pp. 91-103, 2000.

[29] B. Tache, D. Irwin, "Traditional institutions, multiple stakeholders and modern Perspectives," In Common property: Accompanying change within Boran pastoralist systems, 2003.

[30] R. Walker, H. Omar, "Pastoralists Under Pressure: The Politics of Sedentarisation and Marginalization in Wajir District, Northeast Kenya," A Study Report for OXFAM GB, 2002.
[31]D. Western, D. Nightingale, "Environmental Change and the Vulnerability of Pastoralists to Drought: Maasai in Amboseli," in Africa Environment Outlook Case Studies, United Nations Environment Programme, Nairobi, 2003.

[32] H. Whittaker, Pursuing Pastoralists: The Stigma of Shifta during the ,Shifta War"e in Kenya, 1963-68, School of Oriental and African Studies, London, 2008.

\section{Author Profile}

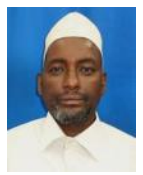

Nur Ibrahim Mohamed just completed his masterse degree in the department of Peace, Security and Social Studies of Egerton University. He was pursuing a Master of Arts Degree in Sociology. Nur is currently the Program Coordinator of CARE International in

Somalia.

Dr. Eric Kiprono Bor is a Senior lecturer and Consultant in the Department of Peace, Security and Social Studies of Egerton University. Dr. Bor is also a consultant on Peace and security matters.

Professor Abdullahi Aboud is a Senior lecturer in the Department of Natural Resources of Egerton University. 